\title{
Comparative Study on the Epidermal Features of Seven Varieties of Vigna Unguiculata (L.) Walp Cultivated in Anambra State South Eastern Nigeria
}

\author{
Aziagba Bibian O., , Okeke C.U., Ilodibia Chinyere V., Ezeabara Chinelo A., Izundu Alexander I., \\ Uka Chiedozie J.
}

Department of Botany, Nnamdi Azikiwe University, Nigeria

Copyright $\bigcirc 2017$ by authors, all rights reserved. Authors agree that this article remains permanently open access under the terms of the Creative Commons Attribution License 4.0 International License

\begin{abstract}
A study was carried out on the leaf epidermal of seven varieties of Vigna unguiculata (L.) Walp, family Fabaceae cultivated in Awka, Anambra State Nigeria. Leaves of the plants were assessed for their phylogenetic relatedness through diagnostic epidermal studying of the cell shapes, anticlinal wall types and stomatal characteristics at the abaxial and adaxial surfaces. The cell shapes, anticlinal wall types and the stomatal characteristics revealed some correlations among the studied taxa. All the seven varieties possess stomata on both the abaxial and adaxial surfaces signifying amphiostomatic. The distribution of the stomata varies and no variations were observed in the cell wall, contours and thickness. Stomata distribution was more on the abaxial layer than the adaxial layer and was mainly paracytic. Features of the quantitative morphology as the stomatal index (SI) were detailed in this study. Result of the epidermal features of the studied taxa revealed their intraspecific relationship and some diagnostic characteristics that could be used for taxonomic decision.
\end{abstract}

Keywords Vigna Unguiculata, Epidermal, Phylogenetic, Stomata

\section{Introduction}

The genus Vigna, Fabaceae formerly Leguminosae, (peas or beans) is composed of more than 200 species that are native to the warm regions of both the old world and new world. It is one of the several species of the widely cultivated Vigna; belonging to the kingdom Plantae, family Fabaceae called Papillionaceae and sub-family, Fabiodeae. It is also one of the most ancient human food sources and has probably been used as a crop plant since Neolithic times. Vigna unguiculata (L.) Walp (cowpea) is an annual dicotyledonous legume and a warm weather crop, well adapted to drier regions of the tropics like Nigeria, where other food legumes do not thrive well [1] Morphological characters are features of external forms or appearance which currently provide the characters used for hypothesizing phylogenic relationships. Morphological characters are easily observed and find of practical use in keys and description. Vigna unguiculata has a large morphological diversity found within the crop, and the growth habit ranges from indeterminate to fairly determinate with the non-vining types tending to be more determinate. Conditions and grower preferences for each variety vary from region to region. [2]. [3] reported that morphological variability in cowpeas (Vigna unguiculata (L.) Walp abounds in the tropics. Poor concern for available but unutilized cowpea variants may promote the losses of diversity in the species. The wide range among the plant genotypes are in shape, size and number of leaves produced by plants. In cowpea, the leaf shape is important for taxonomic classification and also for distinguishing cowpea varieties. Morphological characters include the external features of the plant parts as their size, shape and colour. Most plants are classified based on external morphological structures; such as flower and fruits. Some of these structures are seasonal in production; therefore other means of identification and classification need to be involved. The use of epidermal studies is one of such means of micro morphological classification. Distribution of stomata varies between monocots and dicots between plant species and between the underside and top side of the leaves. From available literatures, the use of leaf epidermal features in systematic botany is now popular just like the use of other markers like DNA sequence and chemical compositions $[4 ; 5]$. Epidermal characters are attributes of potential taxonomic significance both in genus and species level found on the leaves of plants. The morphology of stomata and surrounding epidermal cells of 
the leaf have long been regarded as useful tools [6; 7]. [8,] [9] and 10] were among the early workers that observed the tendency of the cells surrounding the general cells of the stomata to form patterns which were constant within taxa and even families and proposed different terminologies for the description of these cells in recent times. [11]; [12]; [5] reaffirmed that epidermal and particular traits of plants could serve as vital in systematic of the present day angiosperms. Shapes of the epidermal cells, subsidiary type and arrangement of stomata, size and shape of trichomes and number of vascular bundles are all vital in systematic botany [13]. Epidermal structures and stomatal ontogeny of some Nigerian ferns are now seen as relevant in their recognition [14]. [15] compared the morphology of the leaf epidermis in Annona and suggested the utilization of this character in the identification of the species. Perhaps the most extensive investigated family where anatomical features provided very useful taxonomic characters was the Gramineae and several authors have constructed keys for the identification of the taxa within the family based only on leaf epidermal characters [16]. [12] used the leaf epidermal morphology of some members of Costus senna and Boerhavia species to establish possible relationships among the different species they investigated. Leaf anatomical characteristics have been studied in most families of monocot and dicot but much has not been established. This study therefore was aimed at revealing the diagnostic comparative of the leaf epidermal features of seven varieties of Vigna unguiculata that could be used for grouping them taxonomically.

\section{Materials and Methods}

The fresh leaves of the matured plants of Vigna unguiculata varieties; Ifebrown beans, Oloka, Kafanji, Iron beans, Sokoto guzo, Potiskum Crowder peas/blackbeans were collected from the Botanical garden of Nnamdi Azikiwe University Awka. The seven varieties were identified and authenticated by Taxonomists Prof. C.U. Okeke and Aziagba Bibian .O. of the Department of Botany Nnamdi Azikiwe University, Awka and deposited at the Hebarium of the Department.

\section{Epidermal Studies}

Small portion of the fresh matured leaves was used for the studies. The epidermal imprints of the leaf lamina were prepared .This was done by applying a domestic adhesive (Quick fix) uniformly on both the upper and the lower epidermis of the leaves. This was then dried at room temperature. The dried transparent film of the "Quick fix" was stripped off carefully from the surface of the leaf and then placed on a clean dry glass slide with imprint surface uppermost. Cover slip was placed lightly over it to flatten the film. The thin film was then observed under a compound microscope. Photomicrographs were taken using a Leity Ortholux microscope fitted with a Vivatar-V- 335 camera.

The stomatal index was determined according to [17], using the formular:

Stomatal Index: $\mathrm{S} . \mathrm{I}=(\mathrm{S} / \mathrm{S}+\mathrm{E}) \times 100$.

Table 1. Summary of epidermal characters of Vigna unguiculata (.L.) Walp

\begin{tabular}{|c|c|c|c|c|c|}
\hline Characters & Stomatal index $(\%)$ & Epidermal cell shape & Stomata type & Cell wall thickness & Epidermal contours \\
\hline Iron beans & $\begin{array}{l}8.0 \text { U.E } \\
8.82 \text { L.E }\end{array}$ & Irregular & Paracytic & Moderately thick & Curved \\
\hline Ifebrown & $\begin{array}{l}\text { 13.04 U.E } \\
\text { 15.39 L.E }\end{array}$ & Irregular & Paracytic/Anosocytic & Moderately thick & Curved \\
\hline Oloka & $\begin{array}{l}8.57 \text { U.E } \\
23.08 \text { L.E }\end{array}$ & Irregular & Paranjicytic & Moderately thick & Curved \\
\hline Kafanji & $\begin{array}{c}8.85 \text { U.E } \\
\text { 17.81 L.E }\end{array}$ & Irregular & Paracytic & Moderately thick & Curved \\
\hline Potiskum & $\begin{array}{l}\text { 9.09 U.E } \\
\text { 15.39 L.E }\end{array}$ & Irregular & Paracytic & Moderately thick & Curved \\
\hline Crowderpeas & $\begin{array}{l}\text { 16.67 U.E } \\
\text { 22.58 L.E }\end{array}$ & Irregular & Paracytic & Moderately thick & Curved \\
\hline Sokoto guzo & $\begin{array}{l}\text { 16.69 U.E } \\
\text { 24.24 L.E }\end{array}$ & Irregular & Paracytic & Moderately thick & Curved \\
\hline
\end{tabular}

Note: U.E: Upper_epidermis

L.E: Lower_epidermis 


\section{Results and Discussion}

Stomata are homologous structures and of universal occurrence in plants. Stomatal characters have been very useful in taxonomic delimitation; this is apart from their functional relevance in evapotranspiration. Comparative studies by [18] used these stomatal characters in the taxonomic consideration at the sub-generic level. Results of the leaf epidermal features of the seven varieties of Vigna unguiculata (L.) revealed similarities and differences at the abaxial and adaxial features of the micro morphology. The results were represented in Table1 and fig1-14. All the seven varieties have irregular shape of the epidermal wall on both the upper and lower epidermis. The types of stomata for all the varieties were paracytic (parallel celled; one or more of subsidiary cells border the stoma parallel with the long axis of the guard cells) except for Ifebrown that have anisocytic type; (guard cells surrounded by three unequally sized subsidiary cells) on the upper epidermis (Plate 2). The stomatal index varied from $(0.0-16.69 \%)$ in the upper epidermis and $(0.0-24.24 \%)$ in the lower epidermis respectively. Cell wall thickness revealed no variations in all the varieties. Also the epidermal cell wall contours observed were curved in the seven varieties. The epidermal features of the seven varieties of Vigna unguiculata; Var. Ifebrown, Var. Kafanji, Var. Iron beans, Var. Potiskum, Var. Sokoto guzo, Var. Crowder peas, Var. Oloka revealed that the varieties possessed variable and valuable characters in the leaf epidermis that could be used in the systematic delineation of the taxa. The cell wall, cell shape and stomata type revealed correlation among the taxa. The shape of the epidermal cells, types and arrangement of stomata, epidermal cell wall thickness, epidermal cell, wall contours and stomata index are important systematic parameters [14]; [11]. The epidermal cell shape of the seven varieties possessed irregular epidermal cell shape, the cell contours were also curved in the seven varieties (plate 1-14), thus strengthens the intraspecific relationship among the varieties. Stomata index on the other hand varies in the abaxial and adaxial surface of the seven varieties (Table 1). The distribution of the stomata revealed some variations on both the upper and lower surfaces of the seven varieties (Plate 1-14). The stomata at the abaxial are more prominent (Plate 1-7); this could be used as a taxonomic tool in decision making and can also be attributed to adaptation to water loss. The adaxial epidermis of Iron beans and Kafanji revealed the absence of stomata (plate 8 and 11). Some of the varieties possess paracytic and some anisocytic stomata on both the abaxial and adaxial surfaces, while paracytic were more dorminant in the varieties. Anisocytic was revealed at the abaxial surface of Ifebrown (plate 2) which was peculiar among the varieties. The paracytic type of stomata that were characterized in the varieties is not strange since [4] observed the same in Boeheavia species [19] observed the same in some dicotyledonous plants and [5] also noticed the same in Vigna species. The cell wall and cell shape as well as the stomata type revealed correlations among the seven varieties. The description on the structure and development conforms to Metcalfe and Chalk [20] on their work on the epidermal morphology and stomata types in dicotyledons. The results of the epidermal characteristics shared by the seven varieties strengthen their phylogenetic relationship and are important because they help to establish the intra and interspecific relationship among the seven varieties of Vigna unguiculata. The similarities in the leaf epidermal features revealed strong intraspecific relationship and thus suggest the reasons for the seven varieties to belong to the same genus whereas difference on the abaxial surface of Ifebrown (plate 2) which is inconsistent can be as a result of hybrid breakdown in some angiosperms and genus Vigna is not an exception.

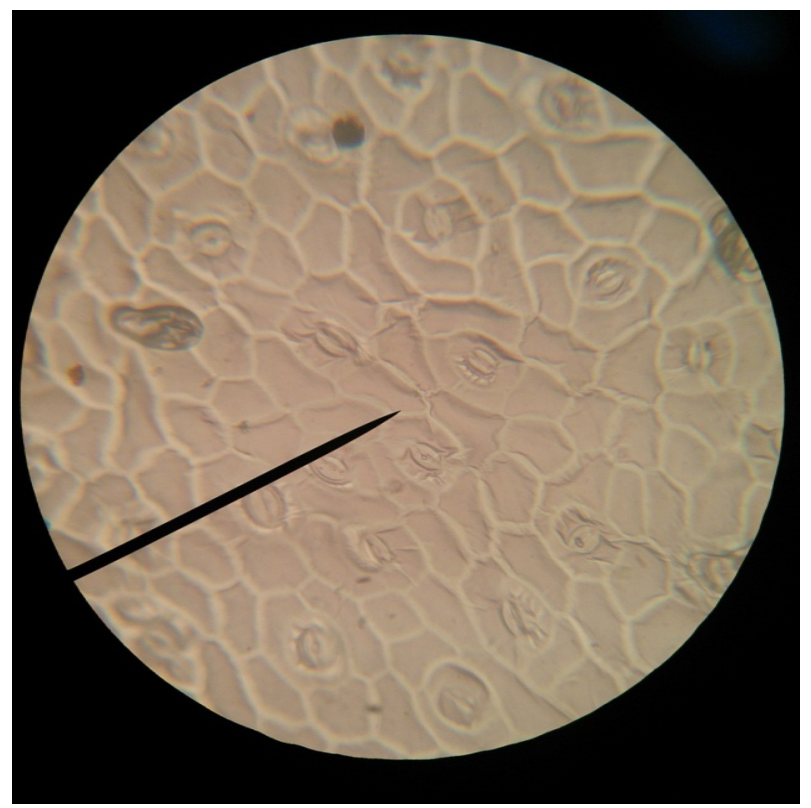

Plate 1. Abaxial or upper surface of Iron beans

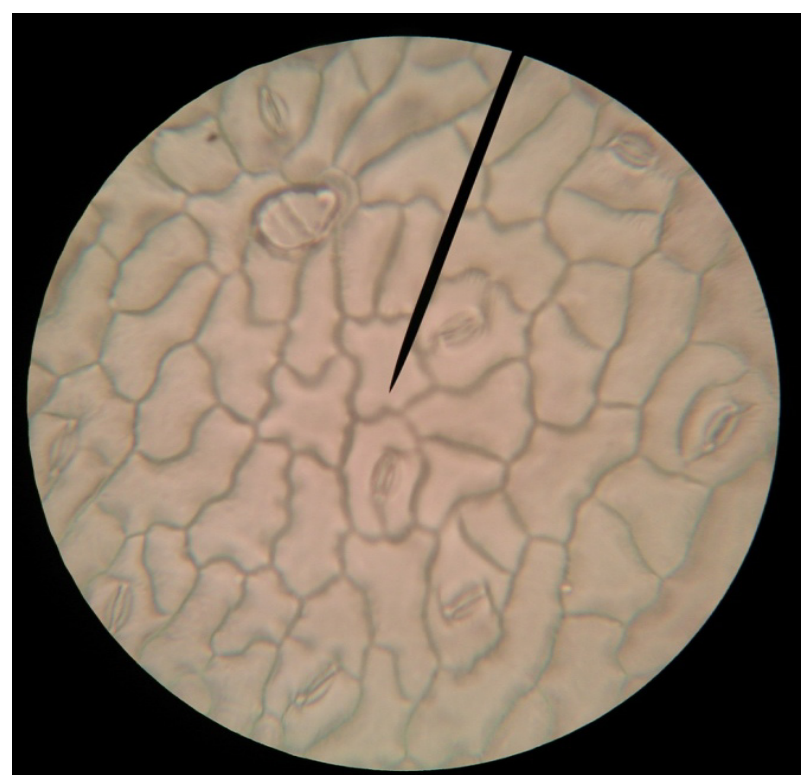

Plate 2. Abaxial or upper surface of Ifebrown beans 


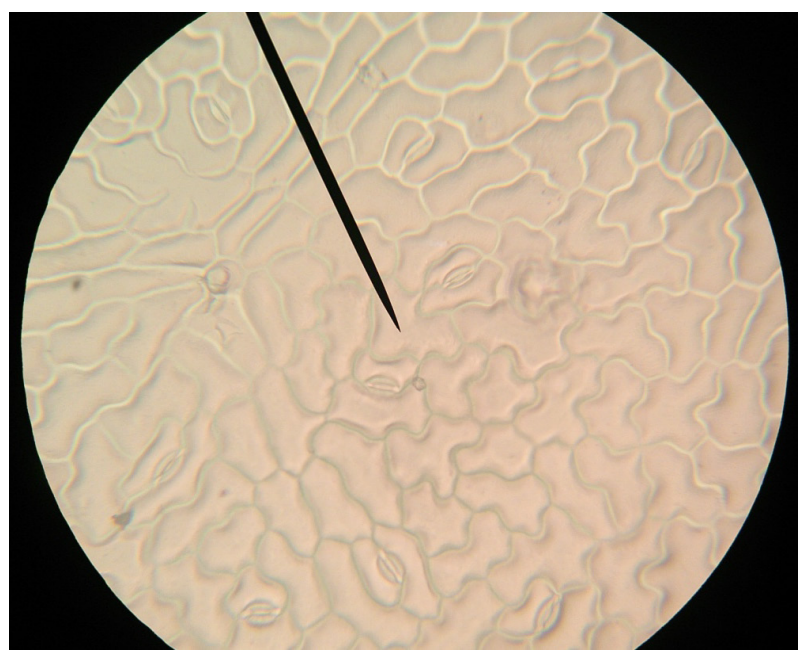

Plate 3. Abaxial or upper surface of Oloka beans

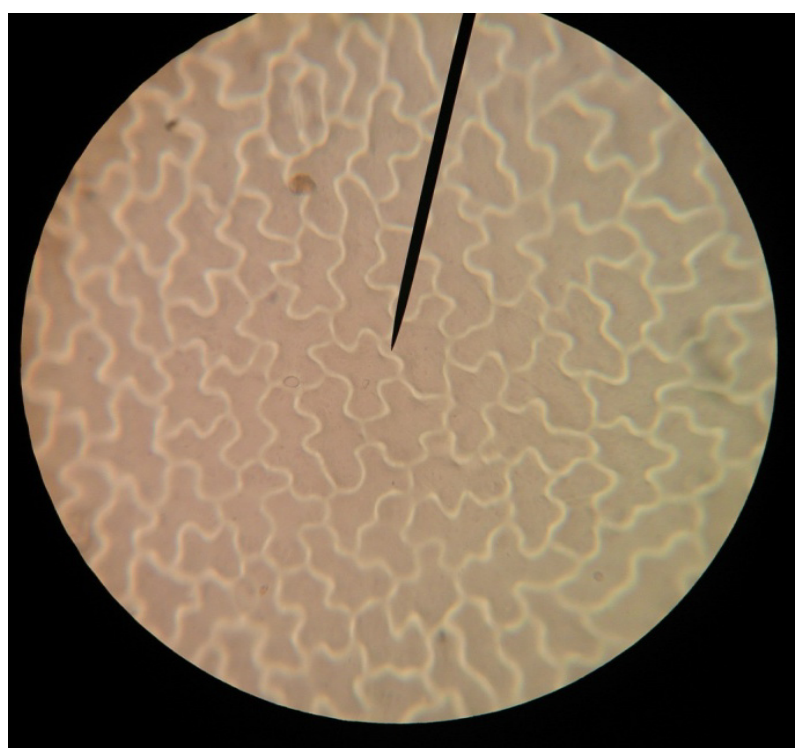

Plate 4. Abaxial or upper surface of kafanji beans

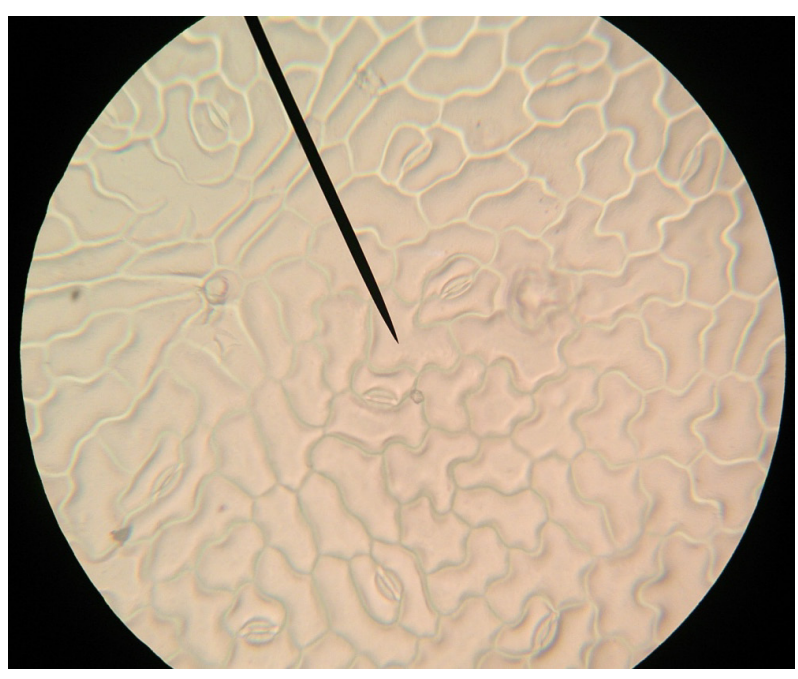

Plate 5. Abaxial or upper surface of Potiskum beans

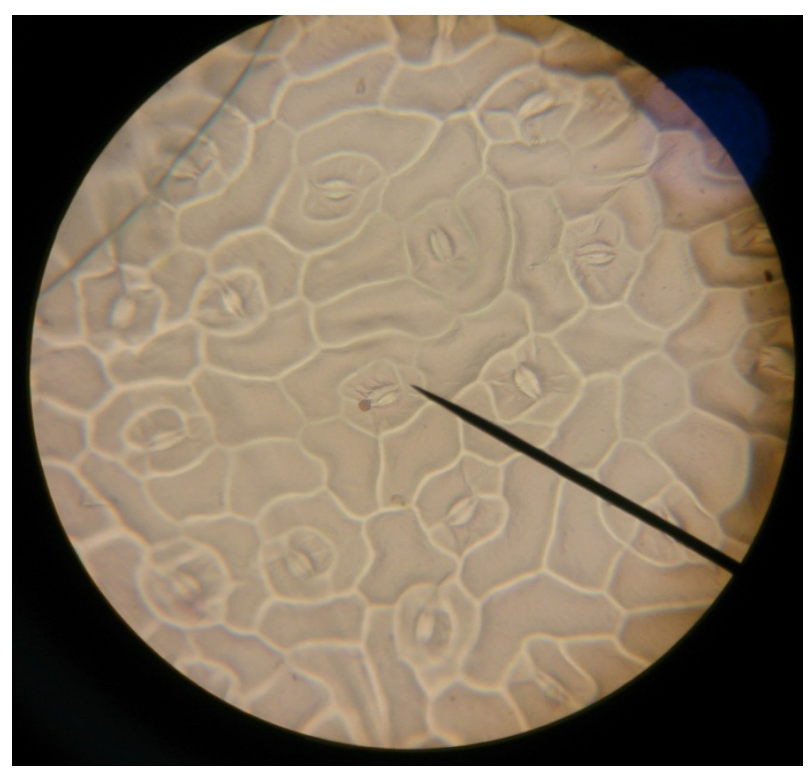

Plate 6. Abaxial or upper surface of Crowther peas

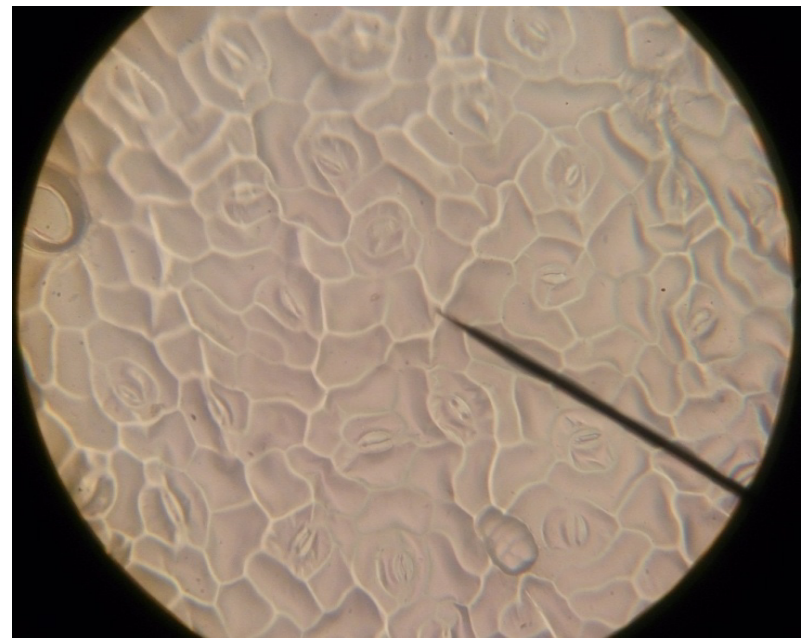

Plate 7. Abaxial or upper surface of Sokoto guzo

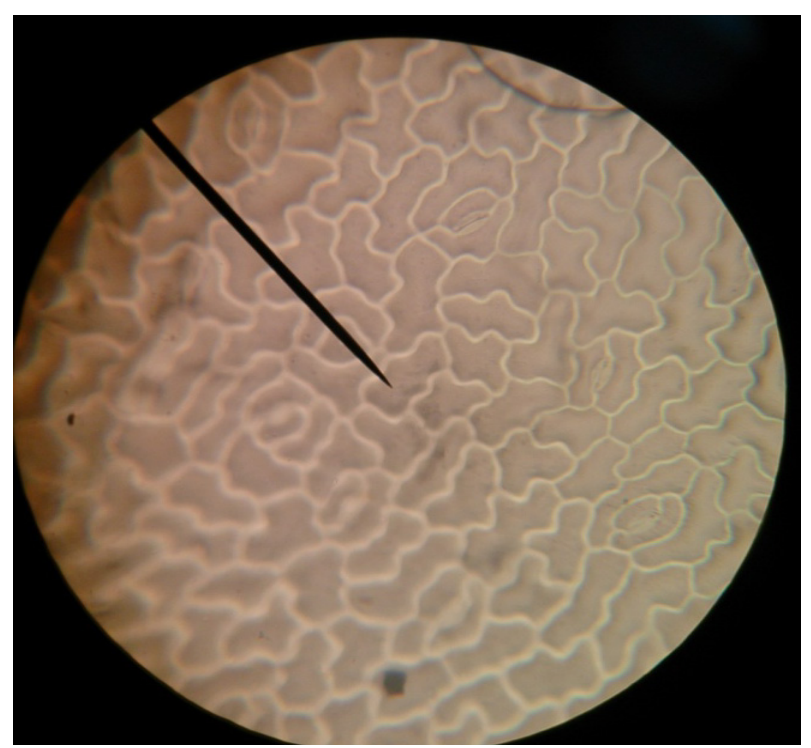

Plate 8. Adaxial or lower surface of Iron beans 


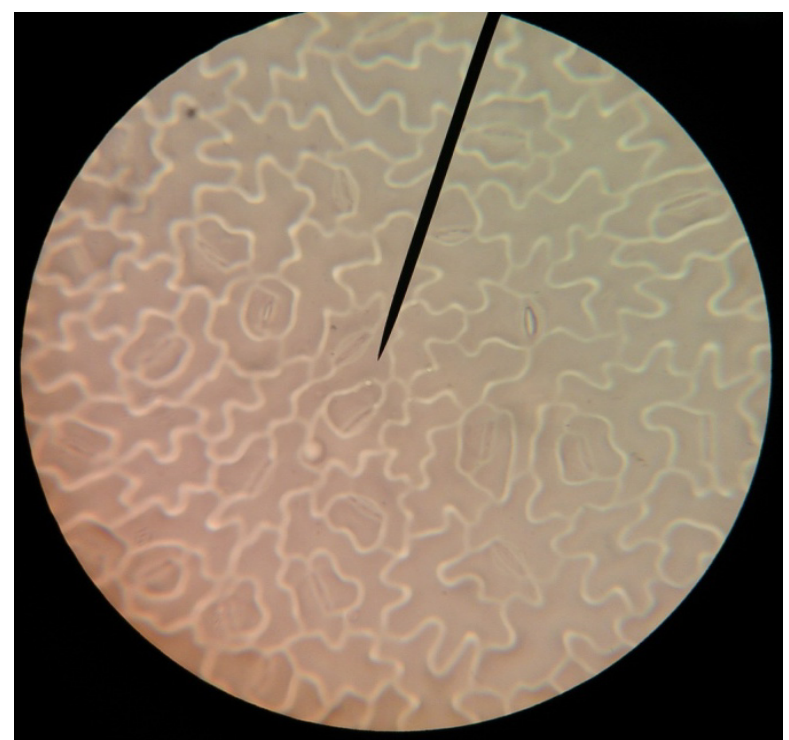

Plate 9. Adaxial or lower surface of ifebrown

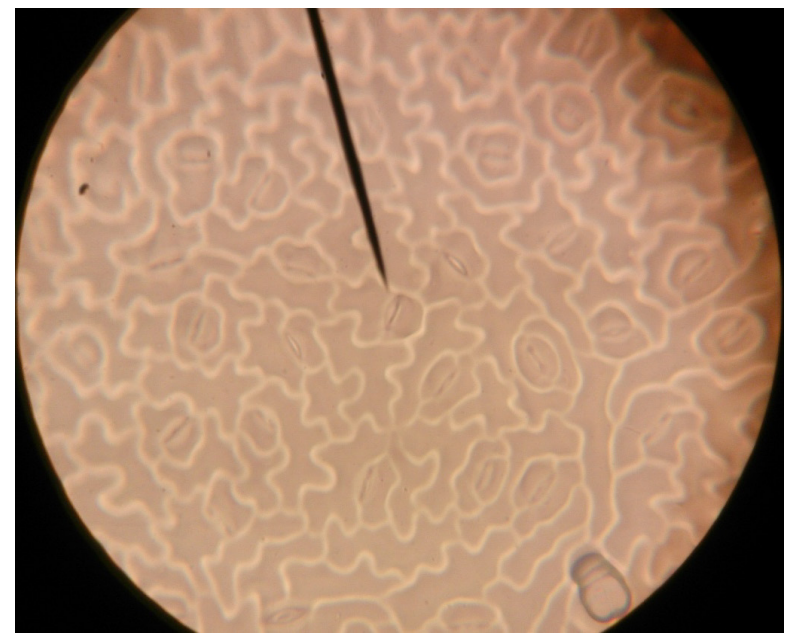

Plate 10. Adaxial or upper surface of Oloka beans

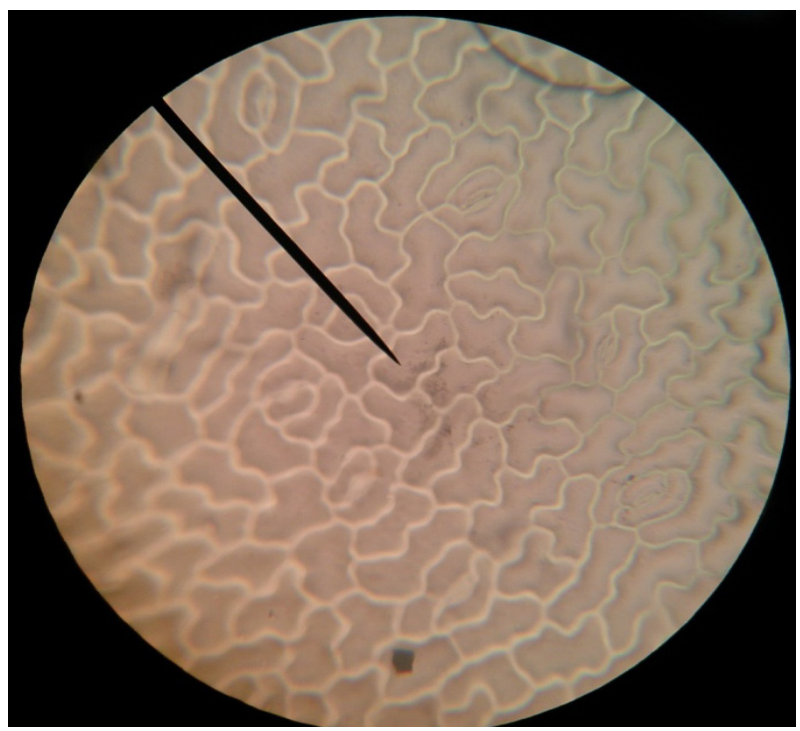

Plate 11. Adaxial or lower surface of. Kafanji beans

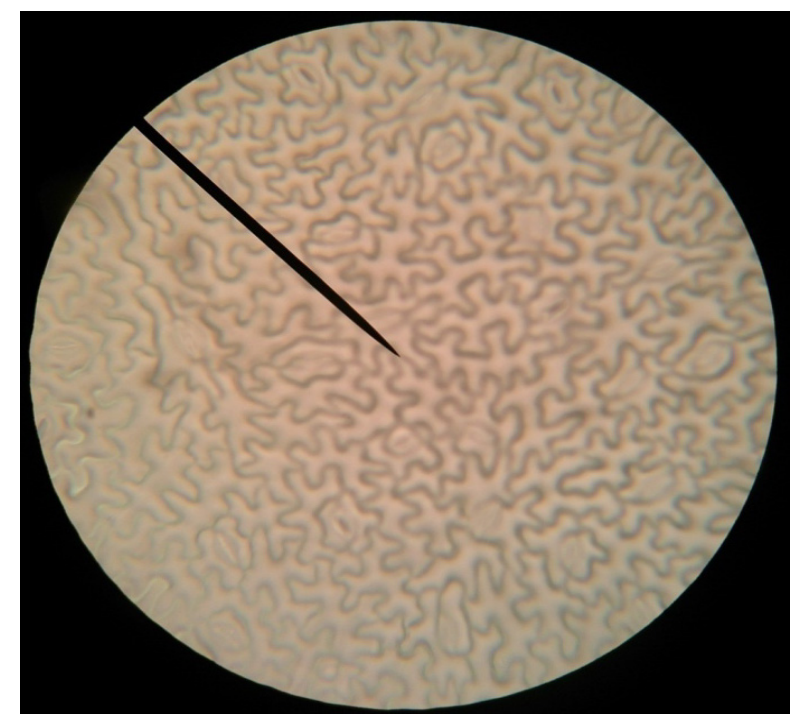

Plate 12. Adaxial or lower surface of Potiskum beans

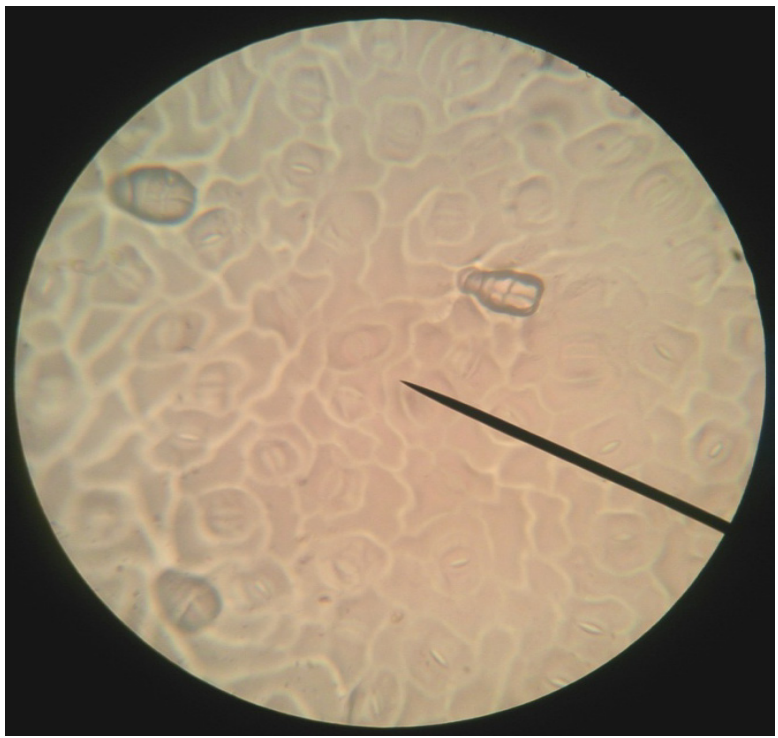

Plate 13. Adaxial or lower surface of Crowder peas

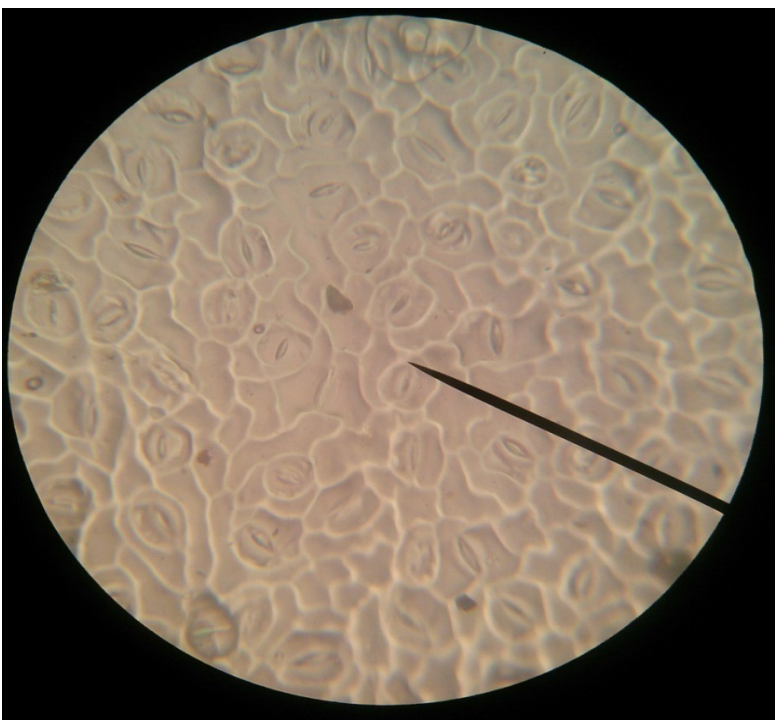

Plate 14. Adaxial surface of Sokoto guzo 


\section{REFERENCES}

[1] Sankie, L., Agbogidi, O. M, Egho, E.O. (2012). Evaluation of eight varieties of cowpea Vigna unguiculata (.L.) Walp. European Journal of Sustainable Development 1 (2): 303-314 ISSN 2239-5938.

[2] Singh, B.B, J.D. Ehlers, B. Sharma F.R. Freire-filho (2002). Recent program in Cowpea Breeding. Challenges and opportunities for enhancing sustainable Cowpea production, instl. institute of tropical Agriculture Ibadan, Nigeria. 22-40.

[3] Porter, W.M. Rachie, K.O., Rawal, R.J. Wein, W and Luse, R.A. (1974), Cowpea germplasm catalogue No 1. IITA Ibadan, 1974. 86-101.

[4] Edeoga, H.O and Ikem, C.I. (2001). Comparative morphology of leaf epidermis in three species of Boerhevia L. Journal of Economic Taxonomy in Botany (19): 197-205.

[5] Mbagwu, F.N and Edeoga, H.O. (2006): Observations on the Vegetation and floral morphology of Some Vigna species (Leguminosae-Papilionoideae).Pakistan Journal of Biological Sciences. (9):1754-1758.

[6] Cutler, D.F. (1978). Applied Plant Anatomy. Part 1 and $112^{\text {nd }}$ Edn. Edward Arnold, London.

[7] Stace, C.A. (1984). The Taxonomic importance of the Leaf Surface .In: Heywood, V.H. and Moore, D.m. (eds) Current Concepts in Plant Taxonomy, London. 67-105.

[8] Payne, W.W. (1970). Heliocytic and allelocytic stomata; unrecognized patterns in the dicotyledonae. American Journal of Botany. 57: 140-147.

[9] Dilcher, D.L. (1974). Approaches to the identification of angiosperm leaf remains. Botany Revolution., 40;1-157.

[10] Wilkinson, H.P.(1979).The plant surface (mainly leaf) In: Metacalfe ,C.R. and Chalk, L., (Eds.) Anatomy of

dicotyledons, Vol.1,2 $2^{\text {nd }}$ edn.97/165.London.

[11] Edeoga, H.O. (1991). Comparative Morphology of the leaf epidermis of Costus afer -Costus lucansianus (Costeceae) complex and its system importance. Nature Science., 24: $1-243$.

[12] Edeoga, H.O. and Osawe, I.O. (1996). Cuticular studies of some Nigerian species of Senna Tourn. Ex Mill. (Syn Casia Tourn. Ex. L): Leguminosae Caesalpinoideae. Acta Phytotaxonomy Geobotany., 47: 41-46.

[13] Nwachukwu, C.U., and Mbagwu, F.N. (2006). Morphological features in some species of Indigofera L. (Leguminosae-Papilionoideae). Journal of fish international, (1): 50-54.

[14] Gill, L.S. and Karatela, Y.Y. (1985). Epidermal morphology and stomatal ontogeny in some West Africa Convolvulaceae species. Herba Hungarice (24):11-17.

[15] Olowokudejo, J.O., 1990. Comparative morphology of leaf epidermis in the genus Annona (Annonaceae) in West Africa. Phytomorphology, 40: 407-422.

[16] Davis, S.I., (1959). The use of epidermal characteristics for the identification of grasses in leafy stage .Journal of $\mathrm{Br}$. Grassland Soc., 14: 7-16.

[17] Metcalfe, C.R. and Chalk, L. (1979) Anatomy of Dicotyledons $2^{\text {nd }}(\mathrm{ed})$ : Clarendon press Oxford London 456-473.

[18] Patil, R.B. and Baviskar, A.P., 1987, Variability studies in cowpea. Journal of Maharashtra Agricultural Universities, 12: 66

[19] Metcalfe, C.R. and L. Chalk, 1960. Analysis of the Monocotyledons. $2^{\text {nd }}$ Edn. Clarendon press, Oxford, pp: 1067-1074.

[20] Metcalfe, C.R. and Chalk, L. (1950) Anatomy of the Dicotyledons (Leguminosae): Leaves, Stems and wood in relation to Taxonomy with Notes on Economics uses. Vol.1.Oxford Clarendon press London 153 